\title{
THE EFFECT OF VIBRATORY AND ROTATIONAL SHOT PEENING AND WEAR ON FATIGUE LIFE OF STEEL
}

\section{WPŁYW KULKOWANIA WIBRACYJNO - ROTACYJNEGO I ZUŻYWANIA STALI NA TRWAŁOŚĆ ZMĘCZENIOWĄ*}

\begin{abstract}
The paper reports the experimental results of investigation of the effect of tribological wear of C45 steel specimens subjected to grinding and vibratory and rotational shot peening on their fatigue life. The study also investigated the effect of wear on surface roughness and the distribution of residual stresses in the surface layer of the tested specimens. Counterspecimen pressure on the specimen was variable during the wear process. Fatigue life was investigated on a specially constructed test stand enabling cyclic bending of the tested specimen. It was found that increasing the counterspecimen pressure leads to an increase in surface roughness and fatigue life as well as generates undesired residual stresses. The negative effects of tribological wear were more visible for the specimens subjected to grinding than for those which were exposed to vibratory and rotational shot peening.
\end{abstract}

Keywords: vibratory and rotational shot peening, wear, surface roughness, residual stresses, fatigue life.

W pracy przedstawiono wyniki badań doświadczalnych wpływu zużywania tribologicznego próbek ze stali C45, szlifowanych oraz kulkowanych wibracyjno - rotacyjnie, na trwatość zmęczeniowa. Badano też wplyw zużywania na chropowatość powierzchni oraz rozkład naprężeń własnych $w$ warstwie wierzchniej badanych próbek. Parametrem zmiennym w procesie zużywania byt nacisk przeciwpróbki na próbkę. Trwatość zmęczeniową badano na specjalnym stanowisku, umożliwiajacym cykliczne zginanie badanej próbki. Stwierdzono, że ze wzrostem nacisku przeciwpróbki następuje pogorszenie chropowatości powierzchni, ukształtowanie mniej korzystnych naprężeń własnych oraz zmniejszenie trwatości zmęczeniowej. Negatywne skutki zużycia tribologicznego bardziej widoczne sa dla próbek szlifowanych niz dla kulkowanych wibracyjno - rotacyjnie.

Stowa kluczowe: kulkowanie wibracyjno - rotacyjne, zużycie, chropowatość powierzchni, naprężenia własne, trwatość zmęczeniowa.

\section{Introduction}

During their operation machine parts can be exposed to varying loads and, at the same time, to sliding or rolling contact with mating components. This leads to the fatigue of material of these parts and their surface wear.

One of the methods for improving operational properties of machine parts is the use of shot peening. A variant of dynamic burnishing, this process consists in impacting a surface with shot in the form of round steel, glass or ceramic particles. This impact leads to the hardening of the surface layer and the production of compressive residual stresses. The results of numerous studies demonstrate that the application of shot peening significantly increases the fatigue life of shot peened parts $[2,4,16,19]$. This increase mainly results from the presence of compressive residual stresses in the surface layer of the workpiece. The findings of tests conducted by the positron annihilation method demonstrate that the distribution of residual stresses is connected with evolution of crystalline structure defects concentration [20]. As in the case of static burnishing, the effect of shot peening greatly depends on the properties of material subjected to shot peening, workpiece shape, geometrical structure of the surface prior to shot peening, tool design and technological parameters $[5,9,18]$.

The geometrical structure of surface and physical properties of the surface layer affect the wear of interacting parts exposed to sliding or rolling $[7,10]$. Wear, described as a process of changes in the surface layer of interacting solids, leading to mass decrement or permanent strain of the surface of these solids, can be caused by different factors, and thus can have different characteristics $[6,8,11]$.

A more wear-resistant surface can be produced by subjecting it to static or dynamic burnishing. The application of some burnishing methods enables forming lubricant-accumulating cavities on the surfaces of frictionally interacting components. The results of studies on wear resistance of slide bearings demonstrate that the forming of a helical groove on the pin surface results in decreased wear [15]. Higher wear resistance, a lower friction factor and higher seizure resistance can be obtained by the application of oscillating burnishing that enables formation of a suitable system of lubricating microgrooves [13]. The presence of oil-accumulating cavities on the interacting surfaces has a positive effect on lubrication but, on the other hand, leads to an increase in unit pressure. It was found that seizure resistance depends on the distribution of lubricant-accumulating cavities and their shape [3]. In shot peening, the impact of shot impacting a surface leads to formation of microcavities which can serve as "lubricant reservoirs." The geometrical structure of surface formed during shot peening can also lead to the occurrence of adhesive "attachments" [14].

Wear leads to changes in properties of the surface layer of interacting components, which can affect their fatigue life. Examples of kinematic nodes in which interacting components are exposed to tribological wear and fatigue of material due to varying loads are given in the work [17]. There are few studies which examine wear and fatigue life at the same time. The study [1] reports the results of wear and fatigue life of titanium alloys used for biomedical implants, while the work [12] investigates the effect of various methods of thermal

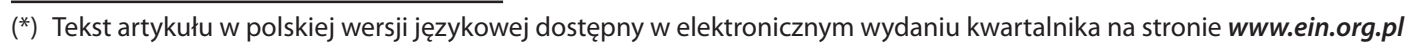


and thermochemical treatment on the fatigue life and friction factor of Ti-6Al-4V alloy.

A survey of the literature reveals that previous research on the effect of vibratory and rotational shot peening on fatigue life did not take account of changes in surface layer properties caused by tribological wear during operation of the tested parts. The aim of this study is to determine the combined effect of vibratory and rotational shot peening and wear during sliding friction on the fatigue life of tested specimens.

\section{Methodology}

The experiments were performed on ring-shaped specimens made of annealed C45 steel and described by the dimensions given in Fig.1a. The chemical composition of the examined steel was as follows: carbon $-0.44 \%$, manganese $-0.57 \%$, silicon $-0.23 \%$, phosphorus $-0.02 \%$, sulfur $-0.03 \%$, chromium $-0.18 \%$, nickel $-0.25 \%$, copper $-0.10 \%$, iron - other. To ensure required surface accuracy, the specimens were subjected to grinding. a)

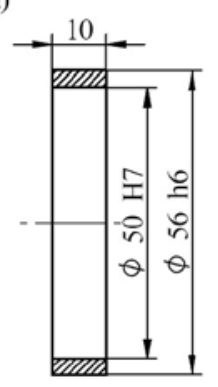

b)

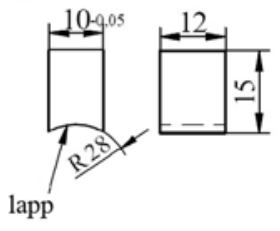

Fig. 1. Shape and dimensions of specimen (a) and counterspecimen (b)

The external surface of prepared specimens was subjected to vibratory and rotational shot peening on a test stand which is schematically illustrated in Fig. 2. The specimens 6 are fixed on a rotating mandrel 3 , its bearings mounted in the walls of a working chamber 2 . The working chamber is set into vibration by a vibrator 1 driven by an electric motor 10. The working chamber 2 contains shot (loose steel balls) 5 which is fed into it after removing a lid 4 . Due to vibration of the working chamber, the shot 5 collides with the external surface of the specimens 6 . The uniformity of treatment of the entire external surface of the specimens 6 is ensured by rotation of the mandrel 3 ,

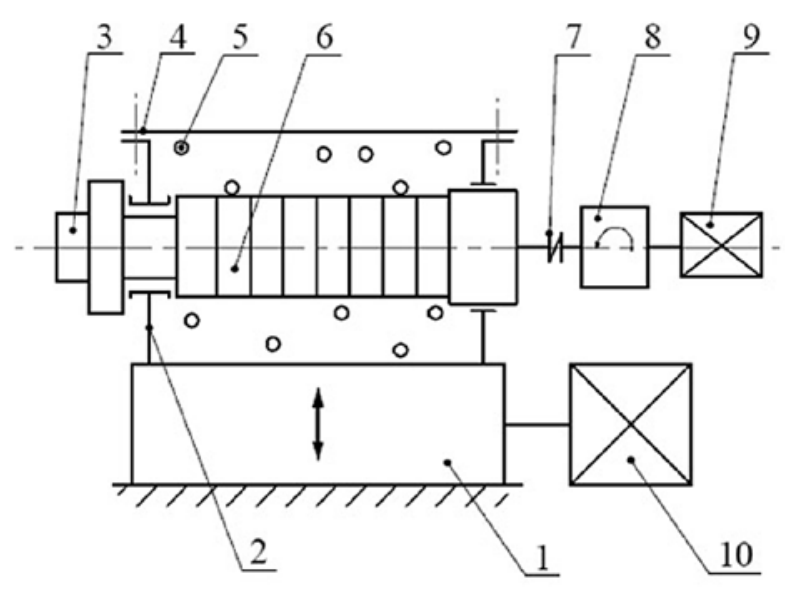

Fig. 2. Schematic design of the stand for vibratory and rotational shot peening tests: 1 - vibrator, 2 - working chamber, 3 - rotating mandrel, 4-lid, 5-shot, 6-specimen, 7-elastic coupling, 8-reducer, 9-electric motor supplying power to mandrel, 10 -electric motor supplying power to vibrator wherein the specimens are fixed. The mandrel 3 receives power from an electric motor 9 via a reducer 8 and an elastic coupling 7 .

The technological parameters of the vibratory and rotational shot peening process were maintained constant at:

- vibration frequency of the vibrator, $v=7 \mathrm{~Hz}$,

- vibration amplitude of the vibrator, $a=60 \mathrm{~mm}$,

- time of shot peening, $t=20 \mathrm{~min}$,

- shot diameter, $d_{k}=6 \mathrm{~mm}$,

- rotational velocity of the workpiece, $n_{k}=1.5 \mathrm{rev} / \mathrm{min}$.

Specimens subjected to grinding with vibratory and rotational shot peening were exposed to tribological wear on a test stand, the schematic design of which is shown in Fig. 3. A specimen 1 was fixed to a spindle 2 rotated with a velocity $n$. The external surface of the rotating specimen 1 was put under load of a counterspecimen 5 mounted in a chuck 6 . Counterspecimens, the shape and dimensions of which are given in Fig. 1b, are made of cast iron EN-GJL-HB195. The pressure on the counterspecimen was applied by means of a lever 4 loaded using weights 3 . The force $\mathrm{F}$ was changed by changing the weight of the weights 3 .

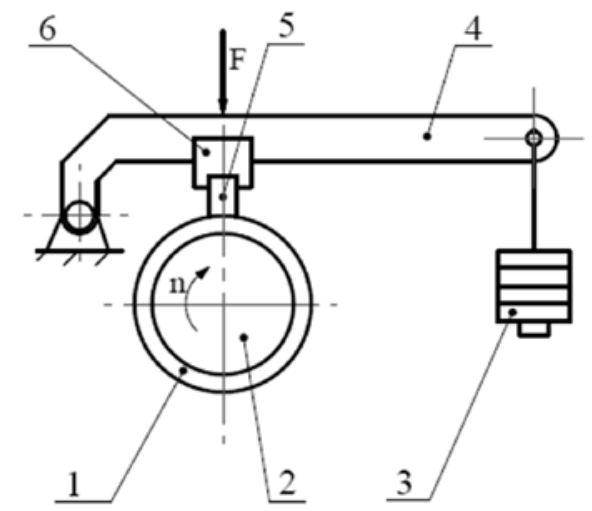

Fig. 3. Schematic design of a device for testing tribological wear: 1 -specimen, 2 - spindle, 3 -weights, 4 - lever, 5 -counterspecimen, $6-$ chuck

The results of preliminary experiments helped determine the conditions for performing tribological tests. The constant parameters were the tangential velocity of the specimen, $v=0.586 \mathrm{~m} / \mathrm{s}$, and the friction path, $s=10584 \mathrm{~m}$. The counterspecimen pressure on the specimen was variable and set to $p_{1}=1.92 \mathrm{MPa}$ and $p_{2}=3.73 \mathrm{MPa}$. Lubrication was done using the HIPOL GL4 oil. Prior to the principal research, the specimen and counterspecimen were subjected to lapping. Following the wear, mass decrement in the specimens was measured (by comparing the difference in specimen mass prior to and after wear).

Worn and unworn specimens were divided into two batches. One was used for examining surface layer properties, the other - for comparative analysis of fatigue life. The surface layer was examined with respect to surface roughness ( $R a$ parameter) and the distribution of residual stresses. The surface roughness parameter $R a$ was measured using the Surtronic $3+$ roughness measuring instrument manufactured by Taylor Hobson. A selection of specimens was also subjected to 3D topography examination made using the T8000RC 120-140 device manufactured by Hommel - Etamic. The distribution of residual stresses was determined by mechanical method (measurement of strains after removal of subsequent layers of specimen material) using nitric acid solution etching.

The next stage of the study involved determination of the fatigue life of worn and unworn specimens after both vibratory and rotational shot peening and grinding. Fatigue life tests were performed on the test stand illustrated in Fig. 4. Prior to the tests, the specimens 


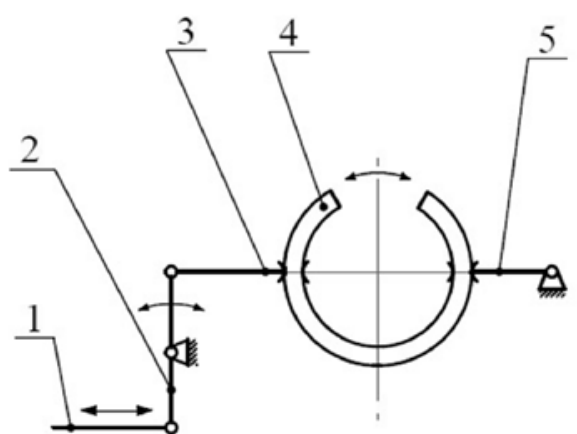

Fig. 4. Schematic design of a device for fatigue life tests: 1 -connecting rod, 2 - lever, 3 - left chuck, 4-specimen, 5 right chuck

were cut in order to remove a part of the ring in the specimen. Thereby prepared specimens were fixed in chucks 3 and 5 . The motion of a connecting rod 1 generated by a lever 2 led to bending of the specimen 4 . The testes were conducted at a constant amplitude of specimen strains. Fatigue life was measured as the number of contraflexures until specimen failure.

Each test was repeated seven times. Based on the results, mean and standard deviations were calculated.

\section{Results}

The investigation of surface roughness and residual stresses was conducted on specimens subjected to grinding and those subjected to grinding with wear as well as on specimens subjected to vibratory and rotational shot peening and those subjected to shot peening with wear.

The results of the surface roughness pa- a)

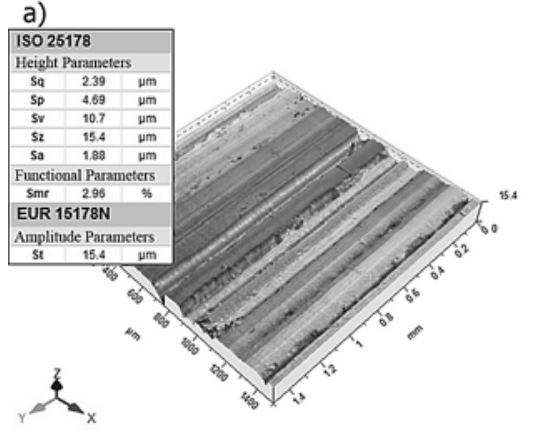

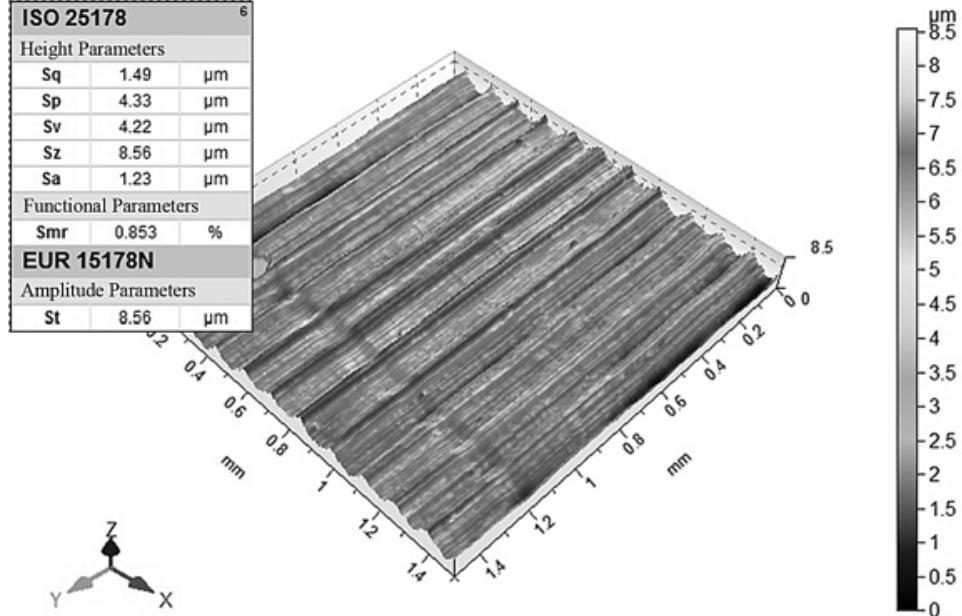

Fig. 6. Specimen surface topography after grinding

b)

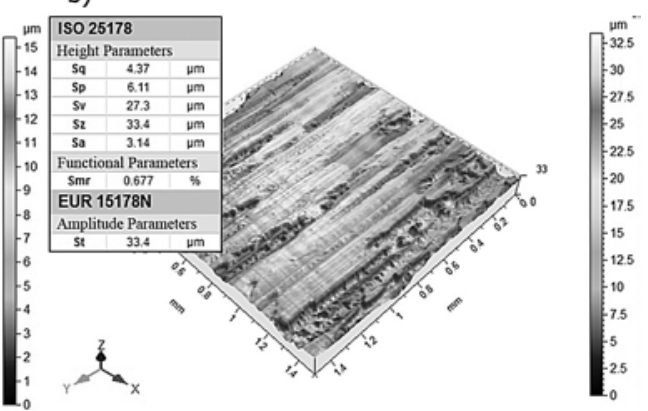

Fig. 7. Specimen surface topography after grinding with wear: a) pressure $1.92 \mathrm{MPa}$, b) pressure 3.73 $\mathrm{MPa}$ rameter $R a$ after grinding and after grinding with wear are illustrated in Fig. 5. The diagram gives mean values of the $R a$ parameter and the error columns show standard deviations. The wear of the ground specimens exposed to a pressure of $1.92 \mathrm{MPa}$ led to a slight increase in $R a$ (by approx. 30\%), while the wear at a pressure of $3.73 \mathrm{MPa}$ led to a significant increase in surface roughness - the $R a$ parameter increased almost by three times (Fig. 5).

Fig. 6 shows the specimen surface topography after grinding while Fig. 7 shows the specimen surface topography following grinding with wear. One can notice visible marks of surface wear, particularly following wear under a pressure of $3.73 \mathrm{MPa}$.

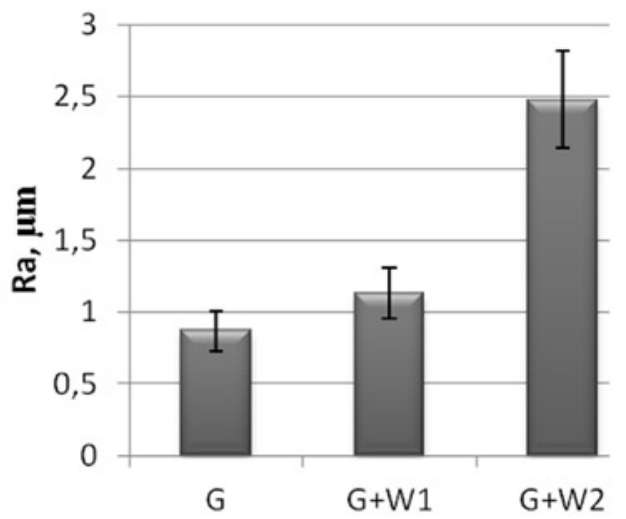

Fig. 5. Surface roughness parameter Ra after grinding $(G)$, grinding with wear under pressures $1.92 \mathrm{MPa}(G+W 1)$ and $3.73 \mathrm{MPa}(G+W 2)$

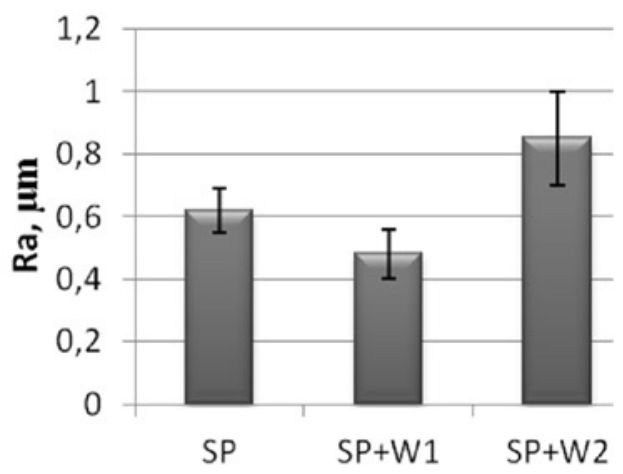

Fig. 8. Surface roughness parameter Ra shot peening after (SP), shot peening with wear under pressures $1.92 \mathrm{MPa}(\mathrm{SP}+\mathrm{Wl})$ and $3.73 \mathrm{MPa}$ $(S P+W 2)$

The application of vibratory and rotational shot peening to the surface subjected to grinding led to decreasing surface roughness by approx. 30\% (Fig. 8). The wear of shot peened surfaces had an insignificant effect on surface roughness. Wear at a pressure of $1.92 \mathrm{MPa}$ resulted in a slight decrease in surface roughness, while wear under a pressure of $3.73 \mathrm{MPa}$ led to a slight increase in surface roughness amounting to $37 \%$.

Fig. 9 illustrates the specimen surface topography after shot peening whereas Fig. 10 shows the topography after shot peening and wear. The surface exposed to shot peening reveals the presence of microcavities produced due to the impact of shot (Fig. 9). As can be seen in Fig. 10a, the shot peening with wear at a pressure of $1.92 \mathrm{MPa}$ 


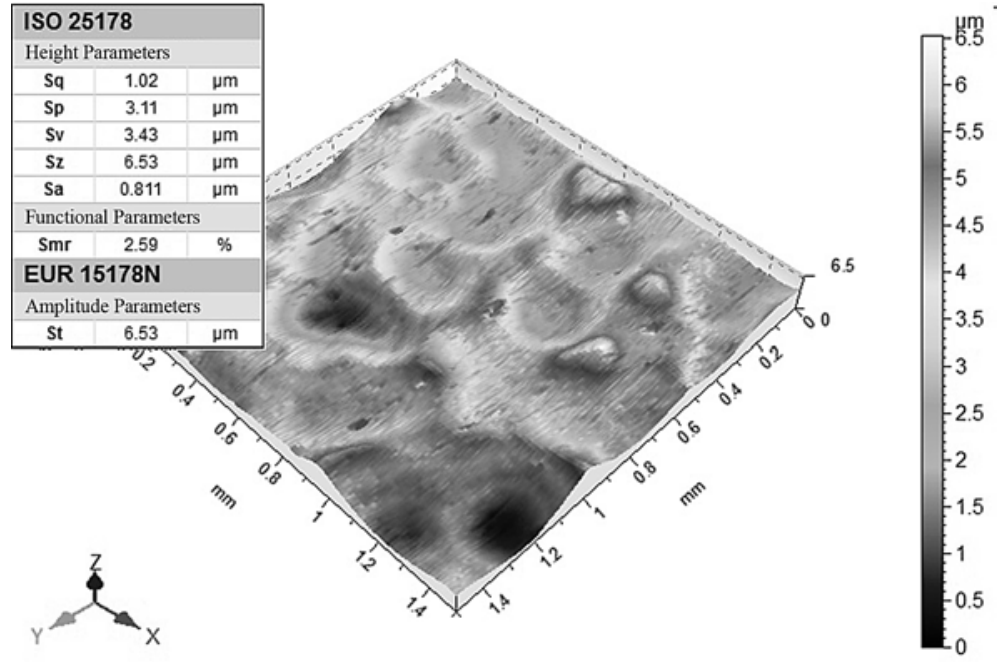

Fig. 9. Specimen surface topography after vibratory and rotational shot peening

a)

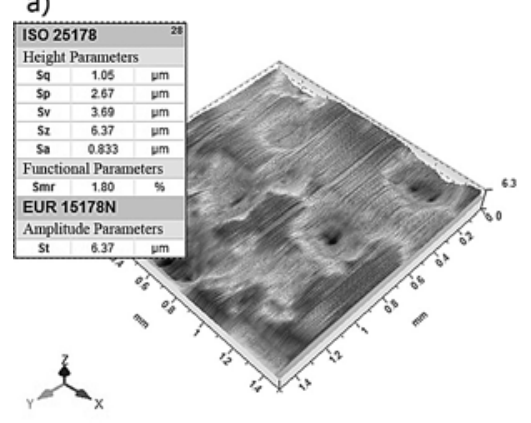

b)

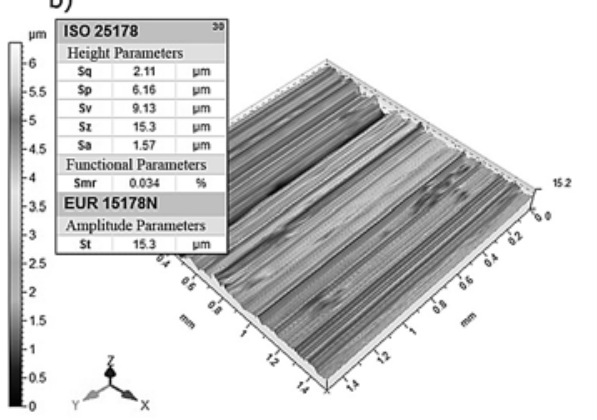

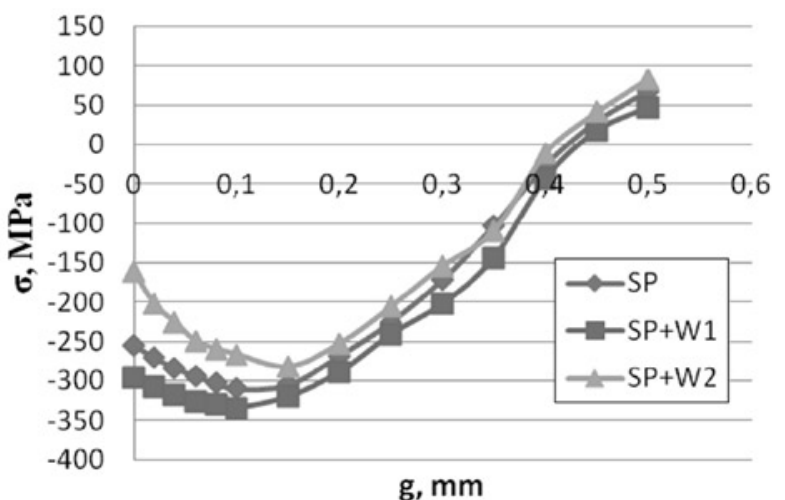

Fig. 12. Distribution of residual stresses $\sigma$ at depth $g$ in specimens exposed to shot peening (SP), shot peening with wear at pressures $1.92 \mathrm{MPa}(\mathrm{SP}+\mathrm{W} 1)$ and $3.73 \mathrm{MPa}(\mathrm{SP}+\mathrm{W} 2)$

The distributions of residual stresses in the surface layer of the tested specimens are shown in Figs. 11 and 12. After grinding, the tensile residual stresses reach up to approx. $90 \mathrm{MPa}$ and, at a depth of $0.13 \mathrm{~mm}$, they change into compressive stresses. The wear of ground specimens at a pressure of $1.92 \mathrm{MPa}$ resulted in a decrease in the tensile residual stresses, both their values and the depth of their location, while increasing the pressure to 3.73 MPa led to an over two-time increase in the tensile residual stresses (Fig. 11).

The application of vibratory and rotational shot peening led to formation of compressive residual stresses in the surface layer, with a maximum (absolute) value of about $300 \mathrm{MPa}$, at a depth of about $0.4 \mathrm{~mm}$ (Fig. 12). The wear of specimens subjected to shot peening at a pressure of $1.92 \mathrm{MPa}$ did not cause any significant changes in the distribution of residual stresses, while in the specimens put under a pressure of 3.73 $\mathrm{MPa}$, the compressive residual stresses decreased, particularly at the surface.

The increase in the tensile residual stresses in the specimens subjected to grinding and the decrease in the compressive residual stresses in the shot peened specimens due to wear at a pressure of 3.73 MPa can result from a larger amount of heat released during wear at higher pressures.

Fig. 13 illustrates the mass decrement due to wear of the specimens subjected to grinding and shot peening. One can observe a higher mass wear of the specimens subjected to grinding compared to shot peened specimens. This can be attributed to improved lubrication of the surface after grinding and, perhaps, to the hardening of the surface layer due to shot peening. The specimen wear also depends on the pressure exerted by the counterspecimen, which can particularly be observed in the case of specimens subjected to grinding (increase in pressure from 1.92 MPa to $3.73 \mathrm{MPa}$ increases wear by three times).

Figs. 14 and 15 show the effect of wear on the fatigue life of specimens subjected to grinding and shot peening. The results reveal a positive effect of vibratory and rotational shot peening on fatigue life (over a three and a half increase compared to the ground specimens). The wear at a pressure of $1.92 \mathrm{MPa}$ had little effect on fatigue life (it slightly decreases after the wear of specimens subjected to grinding), whereas increasing the counterspecimen pressure on the specimen to $3.73 \mathrm{MPa}$ led to a significant decrease in its fatigue life - by $51 \%$ in the case of ground specimens, and by $-18 \%$ in the case of shot peened specimens. The decrease can be attributed to a 


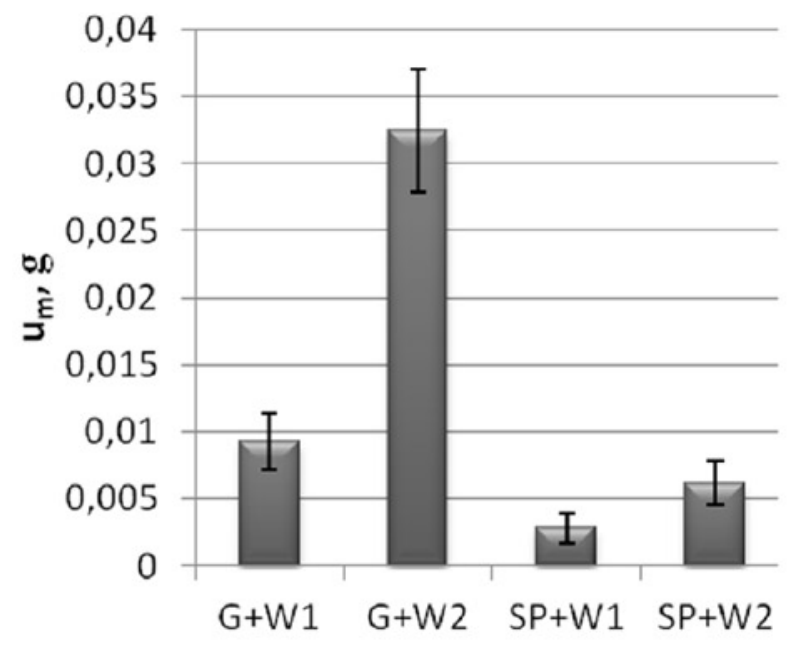

Fig. 13. Mass decrement $u_{m}$ after grinding with wear at pressures $1.92 \mathrm{MPa}$ $(G+W 1)$ and $3.73 \mathrm{MPa}(G+W 2)$ and after shot peening with wear at pressures 1.92 $\mathrm{MPa}(\mathrm{SP}+\mathrm{W1})$ and $3.73 \mathrm{MPa}(\mathrm{SP}+\mathrm{W} 2)$

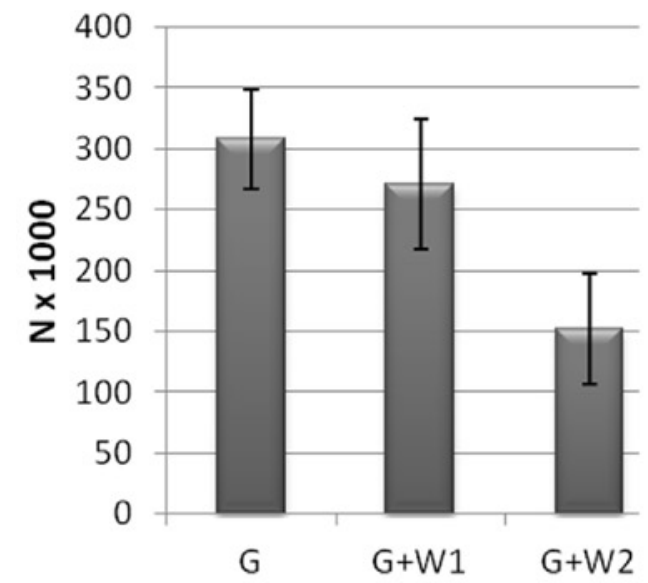

Fig. 14. Number of contraflexure cycles $N$ until specimen failure after grinding $(G)$, grinding with wear at pressure $1.92 \mathrm{MPa}(G+W 1)$ and at pressure $3.73 \mathrm{MPa}(G+W 2)$

less desired distribution of residual stresses and increased surface roughness. These undesired changes in the surface layer properties occur to a lesser extent in the shot peened specimens, which leads to their longer fatigue life.

\section{Conclusions}

The experimental results led to formulation of the following conclusions:

1. The tribological wear of $\mathrm{C} 45$ steel specimens due to the effect of sliding on cast iron counterspecimens at a pressure of 3.73 MPa causes undesired changes in properties of the surface layer, which results in decreased fatigue life of these specimens.

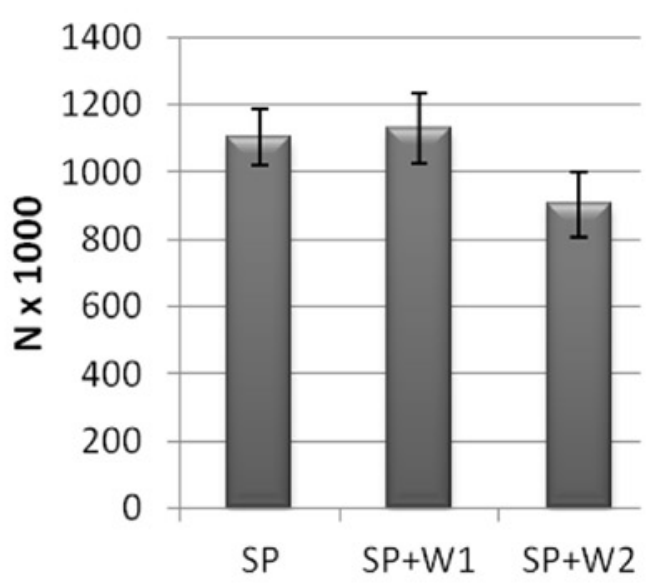

Fig. 15. Number of contraflexure cycles $N$ until specimen failure after shot peening $(S P)$, shot peening with wear at pressure $1.92 \mathrm{MPa}(\mathrm{SP}+\mathrm{Wl})$, and at pressure $3.73 \mathrm{MPa}(\mathrm{SP}+\mathrm{W} 2)$

2. The deterioration in the surface layer properties and the decrease in fatigue life are more visible for the specimens subjected to grinding with wear than for those subjected to shot peening.

3. As for the specimens exposed to wear at a counterspecimen pressure of $1.92 \mathrm{MPa}$, we can observe a slight decrease in the fatigue life of specimens subjected to grinding, while the wear of specimens subjected to shot peening does not significantly affect their fatigue life.

4. Vibratory and rotational shot peening leads to a higher fatigue life of both parts which are not exposed to tribological wear and, to a higher degree, parts which are exposed to the wear process.

5. Vibratory and rotational shot peening also increases tribological wear resistance of parts. The changes in geometrical structure of the specimen surface exposed to shot peening help accumulate oil between the surfaces of interacting components, which leads to a smaller mass decrement of these components.

The practical significance of the investigated problem stems from the fact that machines contain numerous components which are exposed to fatigue and tribological wear at the same time. The application of vibratory and rotational shot peening in the manufacturing of such components, a process which leads to formation of lubricationimproving microcavities on workpiece surface and generation of residual stresses, has a positive effect on operational life of such components.

\section{References}

1. Boehlert C.J, Cowen C.J, Quast J.P, Akahori T, Niinomi M. Fatigue and wear evaluation of Ti-Al-Nb alloys for biomedical applications. Material Science and Engineering C 2008; 28: 323-330, http://dx.doi.org/10.1016/j.msec.2007.04.003.

2. Carvalho A.L.M, Voorwald H.J.C. Influence of shot peening and hard chromium electroplating on the fatigue strength of $7050-T 4751$ aluminum alloy. International Journal of Fatigue 2007; 29: 1282-1291, http://dx.doi.org/10.1016/j.ijfatigue.2006.10.003.

3. Galda L, Dzierwa A, Sep J, Pawlus P. The effect of oil pockets shape and distribution on seizure resistance in lubricated sliding. Tribol Lett 2010; 37: 301-311, http://dx.doi.org/10.1007/s11249-009-9522-7.

4. Korzynski M, Dzierwa A, Pacana A, Cwanek J. Fatigue strength of chromium coated elements and possibility of its improvement with ball peening. Surface \& Coatings Technology 2009 Dec; 204(5): 615-620, http://dx.doi.org/10.1016/j.surfcoat.2009.08.049. 
5. Kulakowska A, Kukielka L, Kukielka K, Malag L, Patyk R, Bohdal L. Possibility of steering of products surface layer properties in burnishing rolling process. Applied Mechanics and Materials 2014; 474: 442-447, http://dx.doi.org/10.4028/www.scientific.net/AMM.474.442.

6. Lawrowski Z. Tribologia. Tarcie, zużywanie i smarowanie. Warszawa: PWN, 1993.

7. Leśniewski T, Krawiec S. Wpływ twardości stalowych materiałów ślizgowych na ich zużycie. Tribologia 2004; 3: $237-245$.

8. Maruda R.W, Feldshtein E.E, Legutko S, Królczyk G.M. Improving the efficiency of running-in for a bronze-stainless steel friction pair. Journal of Friction and Wear 2015 Nov; 36(6): 548-553, http://dx.doi.org/10.3103/S1068366615060082.

9. Matuszak J, Zaleski K. Edge states after wire burnishing of magnesium alloys. Aircraft Engineering and Aerospace Technology: An International Journal 2014; 86(4): 328-335, http://dx.doi.org/10.1108/AEAT-09-2012-0155.

10. Matuszewski M, Styp-Rekowski M. Wpływ kierunkowości struktury geometrycznej powierzchni na intensywność zużywania par ciernych. Tribologia 2007; 2: 469-477.

11. Michalczewski R, Piekoszewski W, Szczerek M, Tuszynski W. The lubricant-coating interaction in rolling and sliding contacts. Tribology International 2009; 42: 554-560, http://dx.doi.org/10.1016/j.triboint.2008.05.001.

12. Morita T, Keita A, Chuji K. Effect of combination treatment on wear resistance and strength of Ti-6Al-4V alloy. Material Science \& Engineering A 2014; 618: 438-446, http://dx.doi.org/10.1016/j.msea.2014.09.042.

13. Przybylski W, Hochschulz R. Technologia wytwarzania mikrorowków na powierzchni tarcia łożysk ślizgowych przez nagniatanie oscylacyjne. Tribologia 1999; 5: 625-638.

14. Rudawska A. Selected aspects of the effect of mechanical treatment on surface roughness and adhesive joint strength of steel sheets. International Journal of Adhesion and Adhesives 2014; 50: 235-243, http://dx.doi.org/10.1016/j.ijadhadh.2014.01.032.

15. Sep J, Pawlus P, Galda L. The effect of helical groove geometry on journal abrasive wear. Archives of Civil and Mechanical Engineering 2013; 13: 150-157, http://dx.doi.org/10.1016/j.acme.2013.01.001.

16. Sledz M, Bak L, Stachowicz F, Zielecki W. Analysis of the effect of shot peening on mechanical properties of steel sheets used as screener sieve materials. International Symposium on Dynamic Deformation and Fracture of Advanced Materials (D2FAM2013). Journal of Physics Conference Series; 2013 Sep (451) Loughborough Univ.

17. Sosnovskiy L.A, Bogdanovich A.V, Yelovoy O.M, Tyurin S.A, Komissarov V.V, Sherbakov S.S. Methods and main results of tribo-fatigue tests. International Journal of Fatigue 2014; 66:207-219, http://dx.doi.org/10.1016/j.ijfatigue.2014.04.006.

18. Zaleski K, Blawucki S. Evaluation of the effectiveness of the shot peening process for thin-walled parts based on the diameter of impressions produced by the impact of shot media. Advances in Science and Technology. Research Journal 2015; 9(26): 77-82.

19. Zaleski K. The effect of shot peening on the fatigue life of parts made of titanium alloy. Eksploatacja i Niezawodnosc Maintenance and Reliability 2009; 4(44): 65-71.

20. Zaleski R, Zaleski K, Gogol M, Wiertel M. Positron annihilation study of aluminum, titanium and iron alloys surface after shot peening. Applied Physics A 2015; 120: 551-559, http://dx.doi.org/10.1007/s00339-015-9214-0.

\author{
Kazimierz ZALESKI \\ Department of Production Engineering \\ Mechanical Engineering Faculty \\ Lublin University of Technology \\ ul. Nadbystrzycka 36, 20-618 Lublin, Poland \\ E-mail:k.zaleski@pollub.pl
}

